\title{
GASTROPROTECTIVE EFFECTS OF VITEX DONIANA LEAF FRACTIONS AGAINST ACETIC ACID INDUCED GASTRIC ULCER MODEL IN ALBINO RATS
}

\author{
OKECHUKWU STEVEN ONWUKWE*, NKIRUKA CHINONYELUM AZUBUIKE, PETER \\ UWADIEGWU ACHUKWU
}

\author{
Department of Medical Laboratory Sciences, Faculty of Health Sciences and Technology, University of Nigeria Enugu \\ Campus, Nigeria
}

*corresponding author: okechukwu.onwukwe@unn.edu.ng

Manuscript received: December 2020

\begin{abstract}
Vitex doniana is used traditionally for the treatment of various gastrointestinal ailments. This study was designed to evaluate the gastroprotective effects of different fractions of $V$. doniana against acetic acid induced gastric ulcers in rats. Diseases free Albino rats were used for the study. After 24 hours of recovery, treatment commenced for 14 days as follows - negative control received no treatment, positive control received $25 \mathrm{mg} / \mathrm{kg}$ body weight of omeprazole orally, groups 3 to $5 \mathrm{received} 250 \mathrm{mg} / \mathrm{kg}$ body weight of ethyl acetate, methanol and hexane $V$. doniana fraction respectively. At the end of administration, the animals were sacrificed and the stomachs excised to measure the ulcerated areas. Histological and immunohistochemical methods were used to evaluate the ulcer healing degree in the excised gastric tissues. The results obtained showed that the methanol and hexane fractions caused significant healing of the ulcers with curative ratios of approximately $97 \%$ and $83 \%$ respectively $(p<0.05)$. Histochemical and immunohistochemical studies suggested that the fractions improved mucin distribution and angiogenesis.
\end{abstract}

\section{Rezumat}

Vitex doniana este o plantă folosită în mod tradițional pentru tratamentul diferitelor afecțiuni gastro-intestinale. Studiul de față a fost conceput pentru a evalua efectele gastroprotectoare ale fracțiilor de $V$. doniana în ulcerul gastric indus cu acid acetic la şobolani sănătoși. După 24 de ore de recuperare, animalele au fost tratate timp de 14 zile după cum urmează controlul negativ nu a primit niciun tratament, controlul pozitiv a primit $25 \mathrm{mg} / \mathrm{kg}$ corp omeprazol pe cale orală, grupurile 3 până la $5 \mathrm{au}$ primit $250 \mathrm{mg} / \mathrm{kg}$ corp din fracțiunile obținute cu acetat de etil, metanol și, respectiv, hexan. La sfârșitul administrării, animalele au fost sacrificate și țesuturile gastrice au fost excizate pentru a măsura zonele ulcerate. Au fost utilizate metode histologice și imunohistochimice pentru a evalua vindecarea ulcerului în țesuturile analizate. Rezultatele obținute au arătat că fracțiunile obținute în metanol și hexan au determinat ameliorarea semnificativă a ulcerelor cu efecte curative de aproximativ $97 \%$ și, respectiv, $83 \%(\mathrm{p}<0,05)$. Studiile histochimice și imunohistochimice au sugerat că fracțiile au îmbunătăţit distribuția mucinei și angiogeneza.

Keywords: Vitex doniana, gastroprotective, gastric ulcers, ethnopharmacology immunohistochemistry

\section{Introduction}

Gastric ulcer is an important gastrointestinal disease affecting a large number of people [1]. Several factors play roles in the pathogenesis of gastric ulcers. The disease is thought to develop when gastric mucosal damaging factors (such as food ingredients, acid, bile acids, pepsin, bacterial products and drugs) overwhelm the gastric mucosal protective factors (such as gastric mucus, gastric epithelial proliferation, blood flow, bicarbonate secretion, prostaglandins and gastric motility) $[2,3]$. Several factors work together in protecting the gastric mucosa from elements that may disrupt its structural and functional integrity. Yandrapu and Sarosiek summarised these factors as mucus layer factors, mucosal surface epithelial factors, microvasculature factors and factors mediating continuous cell renewal and preventing cell death [4].
Vitex doniana (also called Black Plum in English) is a well-known plant widely distributed in South East Nigeria [5]. It has multiple uses as food (both leaves and fruits), medicines and source of fuel. Various parts of the plant are used traditionally for the treatment of gastrointestinal disorders such as diarrhoea, haemorrhoids, constipation and dysentery [6].

Medicinal plants remain a foremost therapeutic alternative for a significant majority of people in the developing world with most depending solely on these plants for meeting their therapeutic needs $[1,7]$. These plants are easily available and cheap to obtain. They also have the advantage of being less toxic and well tolerated by humans since majority of them are already sources of food to local users. A drawback to the use of these natural plant products as medicines is the lack of empirical approach used as the basis for its formulations, dosage of administration, pharmacological 
activity and characterisation. These formulations are thus used mostly based on folkloric and traditional basis [8]. Ethnopharmacological research into plant phytochemicals has provided an important approach in identifying chemical compounds - "novel chemical entities" that may serve as important drug leads. These chemical entities mostly consist of secondary metabolites found in plants including alkaloids, tannins, terpenoids and phenolic compounds like flavonoids [9]. These secondary metabolites especially the polyphenols have been well studied and shown to possess potent antioxidant activities able to neutralise the effects of reactive oxygen species hence conferring such activities as antiulcer, antioxidant and antiarthritis on them $[10,11]$. This study was thus designed to evaluate the gastroprotective effects of $V$. doniana leaf fractions against acetic acid induced ulcers in rats.

\section{Materials and Methods}

\section{Experimental animals}

Adult Albino rats of mixed sex were used for the study. Only rats free from obvious diseases were used. The animals were housed in well ventilated, clean steel cages under controlled lighting (12 hour light/ dark cycle) and room temperature. A two week period of acclimatization for the animals was allowed before the commencement of the studies. All animals had controlled access to commercial rat feed and free access to drinking water throughout the duration of the experiments. They were weighed before grouping and commencing administration in all experiments. International and institutional guidelines on animal experimenting and humane treatment of experimental animals were adhered to throughout the study. The study was approved by the Ethics Committee of our Institution.

Plant materials

Fresh tender leaves of Vitex doniana were collected from their natural habitat in Enugu, Nigeria. The leaves were identified and authenticated at the Department of Plant Science and Biotechnology, University of Nigeria, Nsukka. The leaves were then air-dried under shade and grinded into fine powder using a mechanical grinder. The powder was weighed and stored appropriately in sealed moisture proof bags.

Liquid-liquid solvent partitioning for extract purification The plant powder was fractionated in increasingly polar solvents using a slight modification of the solvent partitioning methods described by Azmir et al., [12] and Brusotti et al., [9]. All solvents and reagents used were of AnalaR ${ }^{\circledR}$ grade from BDH $^{\circledR}$ Limited, Poole England.

$1 \mathrm{~kg}$ of the plant leaves powder was exhaustively extracted in 2 litres of methanol using a Soxhlet apparatus. The extract was evaporated in a rotary evaporator (Biobase ${ }^{\mathrm{TM}}$ RE-2000A, China). The dried extract was suspended in $500 \mathrm{~mL}$ methanol: water $(9: 1$ solution) and partitioned with equal volume of $n$ hexane to extract the hexane fraction. The residue was again suspended in methanol:water (6:4 solution) and partitioned with $500 \mathrm{~mL}$ of ethyl acetate. The methanol:water suspended residue was then evaporated to dryness to serve as the methanol fraction. While the hexane and ethyl acetate partitions were also dried to obtain their respective fractions. Prior to administration, stock solutions of each fraction were made using dimethyl sulfoxide (DMSO) as solvent. Phytochemical analysis of fractions

The phytochemistry profile of $V$. doniana fractions was determined semi quantitatively using slight modifications of the methods described by Trease and Evans [13]. The bioanalytical processes were performed at the Department of Pharmacognosy, Faculty of Pharmaceutical Sciences University of Nigeria Nsukka.

Evaluation of the antioxidant capacity of fractions using DPPH radicals scavenging assays

The 2,2-diphenyl-1-picrylhydrazyl (DPPH) radical scavenging assay was used to determine the antioxidant capacity of the fractions. The assay evaluates the ability of natural products to scavenge free radicals in vitro [14]. The method described by Sharma and Bhat [15] was used to carry out the tests. $1.0 \mathrm{~mL}$ of $10 \mathrm{mg} / \mathrm{mL}$ each of the fractions was mixed $1.0 \mathrm{~mL}$ of $0.8 \mathrm{mmol} / \mathrm{L}$ of the DPPH solution (Merck, India). The mixture was allowed to stand for 30 minutes after vigorous agitation after which the absorbance was read at $517 \mathrm{~nm}$ against a reagent blank using a benchtop spectrophotometer (Hinotek ${ }^{\mathrm{TM}}$ S23A, China). Ascorbic acid was used as the standard. The percentage inhibition of the fractions for scavenging DPPH radicals was calculated using the formula:

[1 - (absorbance of sample/absorbance of control)] x 100 .

The reactions were run in triplicate and the mean percentage inhibition recorded.

Evaluation of gastroprotective and ulcer healing effects of fractions

Five groups $(\mathrm{I}-\mathrm{V})$ of six Albino rats each were used for this experiment. Chronic ulcers were induced in all the animals using acetic acid described by Polo et al. [3]. Briefly, after an overnight fast, under light anaesthesia laparotomy was performed on the animals via a midline incision on the rats' stomachs. On exposure of the gastric walls, $0.05 \mathrm{~mL}(\mathrm{v} / \mathrm{v})$ of a $30 \%$ acetic acid solution was applied for 20 seconds onto the serosal surface of the glandular portion of the anterior wall of the stomach using a syringe (without the needle) to ensure uniform diameter of exposure. The stomach was then bathed with normal saline, returned into the cavity and sutured. All operated animals returned to their cages to recover for 24 hours prior to the commencement of treatment with water/vehicle, standard drug or extract for 14 days while concurrently being fed normally. 
Animals in Group I served as the negative control and received neither drug nor fraction but received the DMSO vehicle. Group II served as the positive control and received omeprazole at a dose of $25 \mathrm{mg} /$ $\mathrm{kg}$ body weight. Groups III - V received $250 \mathrm{mg} / \mathrm{kg}$ body weight of ethyl acetate, methanol and $n$ hexane fractions respectively. At the end of the treatment, the animals were sacrificed under chloroform anaesthesia and stomach excised and analysed.

Macroscopic, Histochemical and Immunohistochemical analysis of excised stomachs

Macroscopic analysis. The ulcerated regions in the stomach of each animal were analysed and the total area ulcerated in $\mathrm{mm}^{2}$ was recorded using a slight modification of the method described by LanderiaFernandez [16]. In addition to the visual measurement of the ulcer areas, ImageJ software - Fiji ${ }^{\circledR}$ [17] was used to measure the ulcer area with a view to minimise observer bias. Percentage curative ratio (CR) for each treatment group was computed using the formula by Andrade et al. [18]:

100 - ([mean total area of ulcer in treated animals/ mean total ulcer area in untreated control] x 100).

Tissue histology and histochemistry. The excised stomach tissues were fixed in $10 \%$ formol saline, processed into paraffin blocks and 5 micron sections obtained from the blocks. For each stomach tissue, sections were stained with Haematoxylin and Eosin $(\mathrm{H}$ \& E) for general tissue demonstration and Periodic Acid Schiff (PAS) for demonstrating mucins and goblet cells [19].

Immunohistochemical studies. Immunohistochemical methods were employed to assess re-epithelisation (using Ki67 - a known marker of cell proliferation) [3]. Neovascularisation was assessed using an angiogenesis marker - PECAM-1 [20]. Antibodies to both Ki67 and PECAM-1 (Dako ${ }^{\circledR}$, USA) were used to demonstrate reactivity or otherwise using methods described in Bancroft and Gamble [19] with slight modifications.

Briefly, heat assisted epitope retrieval method was developed using $6 \%$ citrate buffer. A solution of $3 \%$ hydrogen peroxide and $15 \%$ albumin was used for endogenous peroxidase and protein blocking respectively. Reactivity of the antibodies were developed using horseradish peroxidase and 3,3 diaminobenzidine (DAB) and sections were counterstained with haematoxylin for contrast. The Fiji software with ImmunoRatio plugin [21] was used for an analysis of the reactivity of Ki67 in the gastric mucosa. This was done in order to reduce observer bias and establish a correlation with visual assessment. The plug-in is designed to calculate percentage $\mathrm{DAB} / \mathrm{Nuclear}$ ratio. The means were compared and plotted in bar charts for each group. Data analysis

IBM $^{\circledR}$ Statistical Package for Social Sciences (SPSS ${ }^{\circledR}$ ) Version 20 was used for the analysis of data generated. GraphPad Prism ${ }^{\circledR}$ V 7 was used to generate the graphs presented. All numerical data generated were subjected to preliminary exploratory statistics and where necessary, have been expressed as percentage or mean \pm standard error of mean. Statistical significance was determined by one-way analysis of variance (ANOVA) followed by a Dunnett's post hoc test for comparison against the negative control. The significance level was set to $\mathrm{p}<0.05$.

\section{Results and Discussion}

\section{Phytochemical profile of fractions}

A semi quantitative method was employed in determining the phytochemicals present in the various fractions of $V$. doniana. Table I shows the result of the semi quantitative screening of the leaf fractions. All the fractions (hexane, ethyl acetate and methanol) contained terpenoids, phenols and flavonoids with the ethyl acetate fraction having the highest concentration of both phenols and flavonoids. The ethyl acetate and methanol fraction contained tannins while the hexane fraction did not.

Table I

Phytochemical screening of the three different fractions of $V$. doniana

\begin{tabular}{lccc}
\hline \multicolumn{1}{c}{ Phytochemical } & Hexane fraction & Ethylacetate fraction & Methanol fraction \\
\hline Tannins & - & ++ & +++ \\
Alkaloids & - & - & + \\
Flavonoids & + & +++ & ++ \\
Saponins & - & + & + \\
Phenols & + & ++ & ++ \\
Soluble carbohydrates & - & - & ++ \\
Steroids & +++ & - & ++ \\
Terpenoids & + & ++ & + \\
Reducing sugars & - & - & + \\
\hline sent; “+" = slightly present; “++" = moderately present; “+++" = highly present
\end{tabular}

Antioxidant capacity of fractions using DPPH scavenging assay

The percentage inhibition of the different fractions and the control (ascorbic acid) for scavenging DPPH free radicals is shown in Table II.
The ethyl acetate fraction had the highest percentage inhibition among the fractions $(72.57 \pm 0.49)$ followed by methanol and then hexane fraction $(66.27 \pm 1.25$ and $45.88 \pm 0.87$ respectively). All the fractions however 
FARMACIA, 2021, Vol. 69, 6

had significantly lower percentage DPPH inhibition $(\mathrm{P}<0.001)$.

Table II

The percentage inhibition (\%) of the different fractions and ascorbic acid (control) for DPPH free radical scavenging assay

\begin{tabular}{lc}
\hline Fraction $(\mathbf{1 0 0} \boldsymbol{\mu g} / \mathbf{m L})$ & DPPH (\% Inhibition) \\
\hline Hexane & $45.88 \pm 0.87^{*}$ \\
Ethyl acetate & $72.57 \pm 0.49^{*}$ \\
Methanol & $66.27 \pm 1.25^{*}$ \\
Control (Ascorbic acid) & $81.19 \pm 1.21$ \\
\hline
\end{tabular}

Values are presented as mean \pm standard error of mean $(\mathrm{n}=3)$. ANOVA (F ratio $=224.6, \mathrm{P}<0.001$ ) followed by Dunnet's test “*” $=\mathrm{P}<0.001$ when compared with the control group using Dunnet's post hoc comparison.

Effects of fractions on ulcer index (UI) and percentage curative ratio $(C R)$

The effect of a 14 day oral treatment of the rats with the various plant fractions after acetic acid induced ulcer is shown in Table III. All the fractions used exhibited varying degrees of ulcer healing. However, the methanol fraction and hexane fraction were the ones that exhibited a significant ulcer healing ability ( $p=0.0078$ and $p=0.0219$ respectively). The standard drug used (omeprazole) was able to induce healing of the ulcers though not significantly ( $\mathrm{p}=0.0766$ ).

The percentage curative ratio calculated from the ulcer lesions showed that the methanol fraction had the highest curative ratio of $97.43 \%$ while the ethyl acetate fraction had the lowest curative ratio of $55.95 \%$.

Table III

Effect of 14 day oral treatment with various fractions from Vitex doniana $(250 \mathrm{mg} / \mathrm{kg}$ ) on healing the acetic acidinduced ulcer in the stomachs of experimental rats

\begin{tabular}{lccc}
\hline \multicolumn{1}{c}{ Treatment (oral) } & Dose $(\mathbf{m g} / \mathbf{k g}$ bw) & Lesion area $\left.\mathbf{( m m}^{\mathbf{2}}\right)$ & Curative ratio (\%) \\
\hline Negative control & - & $11.39 \pm 4.61$ & - \\
Positive control (omeprazole) & 25 & $2.55 \pm 0.13$ & 77.59 \\
Ethyl acetate fraction & 250 & $5.02 \pm 1.59$ & 55.95 \\
Methanol fraction & 250 & $0.29 \pm 0.22 * *$ & 97.43 \\
Hexane fraction & 250 & $1.96 \pm 1.04 *$ & 82.81 \\
\hline
\end{tabular}

Lesion area is presented as mean \pm standard error of mean $(\mathrm{n}=3-5)$. ANOVA (F ratio $=4.275, \mathrm{P}=0.0223)$ followed by Dunnet's test: “*”, $=\mathrm{P}<0.05, “ * * "=\mathrm{P}<0.01$ when compared to the negative control.

\section{Effect of fractions on gross morphology of ulcerated stomachs}

Figure 1 presents images of the exposed gastric mucosa of an animal from each of the experimental groups. It was observed that animals in the negative control group generally had more ulcerated areas (marked by red circles) than the treatment groups. The animals in the treated groups had less severe ulcerations in their stomach mucosa. The mucosae of animals in the methanol fraction group had completely healed ulcers, while those in the hexane fraction group had ulcers that were almost healed.

General histology of the stomachs from the various treatment groups

The general histology of the stomach tissue was assessed using the haematoxylin and eosin staining method to demonstrate general tissue features. The micrographs of the stomach sections from a representative animal from each of the groups are presented in Figure 1. The stomach section of animals in the negative control group showed ulcerative lesions of the gastric epithelia, granulation tissue in the ulcer bed with infiltration by inflammatory cells. Dilated glands were seen near the base of the ulcer with evidence of gland reconstruction and poor epithelia regeneration seen. Those in the positive control group (omeprazole) showed evidence of regenerated epithelia and glands above the granulation tissue of the ulcer.

The stomach section of animals in the ethyl acetate group showed marked improvement in re-epithelisation and gland reconstruction. The ulcer margins above the granulation tissue were narrowed. The stomach mucosa of animals treated with the methanol fractions appeared normal with physiologic cellular distribution and only a slight sloughing of the epithelia and thickened muscularis mucosae. Finally, those that received the hexane fraction showed significant reepithelisation and gland reconstruction above the ulcer base of the stomach sections.

Effect of administration of fractions on the distribution of mucin in the gastric mucosa of treated animals In the stomach sections stained with Periodic Acid Schiff (PAS) technique for the demonstration of mucins distribution, there was visually noticeable increase in PAS reactivity of the gastric mucosa of animals treated with the plant fraction compared to the negative and positive control. The positive control and fraction treated groups had markedly higher PAS reactivity in both surface and deep glands compared to the negative control group (Figure 1).

Effect of administration of fractions on the reactivity of Ki67 in the gastric mucosa of treated animals

Figure 3 presents micrographs of stomach tissue sections from the various treatment and control groups. The sections were stained using the anti-Ki67 antibody to assess the distribution of Ki67 antigen (a marker of cell proliferation). There was generally no noticeable difference in the intensity of reactivity of Ki67 in the epithelia cells surrounding the ulcer beds in the treated groups compared to the negative control. The omeprazole treated group however appeared to show less $\mathrm{Ki} 67$ reactivity in the gastric mucosa. Also, the 
hexane fraction group had the highest reactivity of Ki67 in their gastric mucosae.

The mean percentage DAB/nuclear ratio for the control and treated sections were computed using immunoratio in FIJI $^{\circledR}$ and is shown in Figure 2. There was no statistically significant difference in the DAB/nuclear ratio between the treated and control groups. However, the positive control group had the lowest percentage while the methanol fraction treated group had the highest.
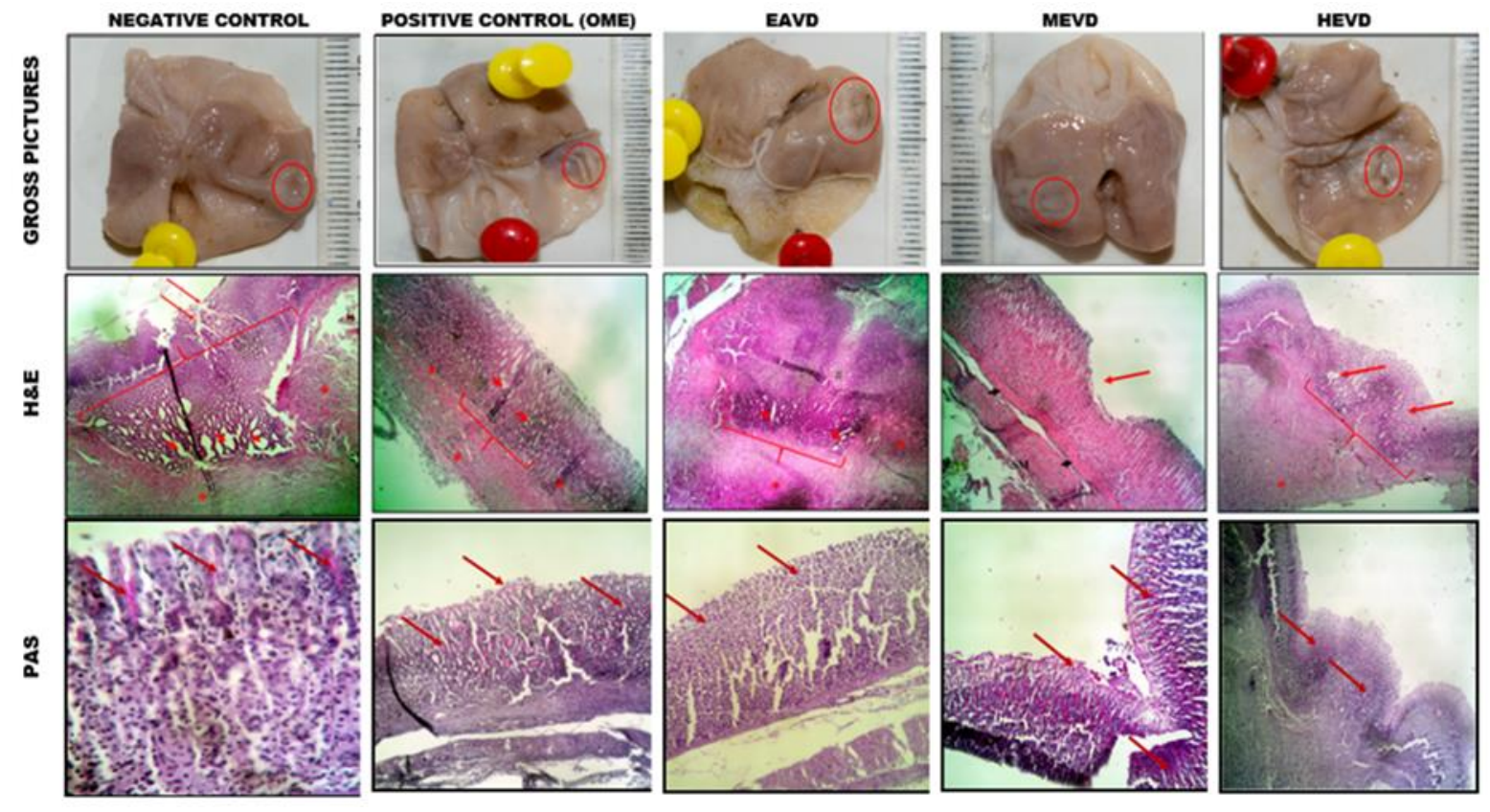

Figure 1.

Grid showing gross images, H\&E and PAS micrographs (rows) of the various treatment and control groups (columns) The red circles in the gross pictures show the ulcerated areas in the rats' gastric mucosa. The brackets in the H\&E sections show the ulcer margins while arrows point the dilated glands undergoing reconstruction above the necrosed ulcer bed.

The arrows in the PAS sections point the mucosal areas that showed PAS reactivity.

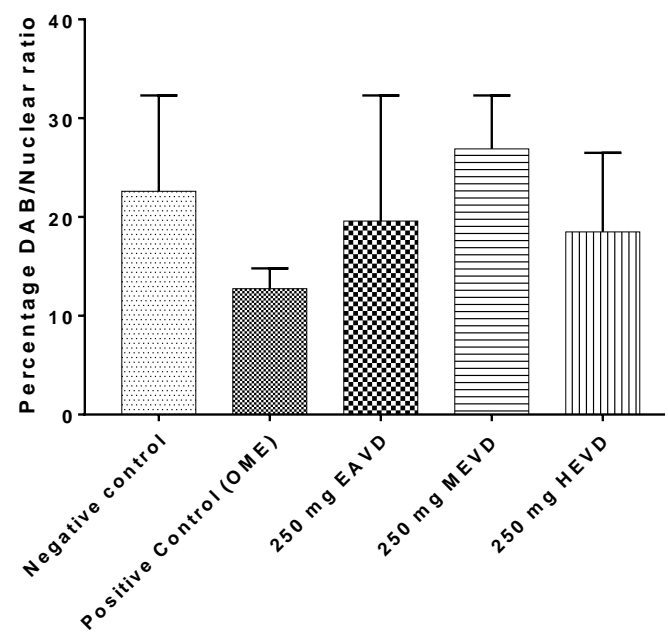

Figure 2.

Mean percentage DAB/nuclear ratio of Ki67 immunostain as measured by immunoratio plug in Image $\mathbf{J}$ The values represent mean \pm standard error of mean for each group

Effect of administration of fractions on the expression of PECAM-1 in the gastric mucosa of treated animals Figure 3 also has micrographs of stomach tissue sections from the various treatment and control groups. The sections were stained with anti-PECAM-1 anti- body to assess the tissue distribution of PECAM-1 (a marker of neovascularisation and angiogenesis). Reactivity of PECAM-1 was observed in all stomach sections of the treated and control animals. However, the reactivity seen in the negative control group was not suggestive of neovascularisation but may be a result of expression in leucocytes seen in the granulation tissue of the ulcer bed. The positive control group did not show such expression. All the treated groups were observed to have mild expression of PECAM-1 in blood vessels suggesting neovascularisation.

The need for cheaper, less toxic and readily available medicinal products from natural sources is increasing. For this reason, a lot of attention has been shifted to research aimed at developing drugs from plant sources [1]. Crude extracts of Vitex doniana leaves have been shown to have antiulcer properties against ethanol induced gastric ulcers among other pharmacological properties [22]. This research was therefore conceived to evaluate the ulcer healing potentials of more refined fractions of the plant leaves and also to better understand the mechanisms that underlie its antiulcer abilities. To do this, the effects of the fractions administration on gastric mucus, Ki67 and PECAM-1 reactivity in the gastric mucosa of ulcer induced animals were assessed. 

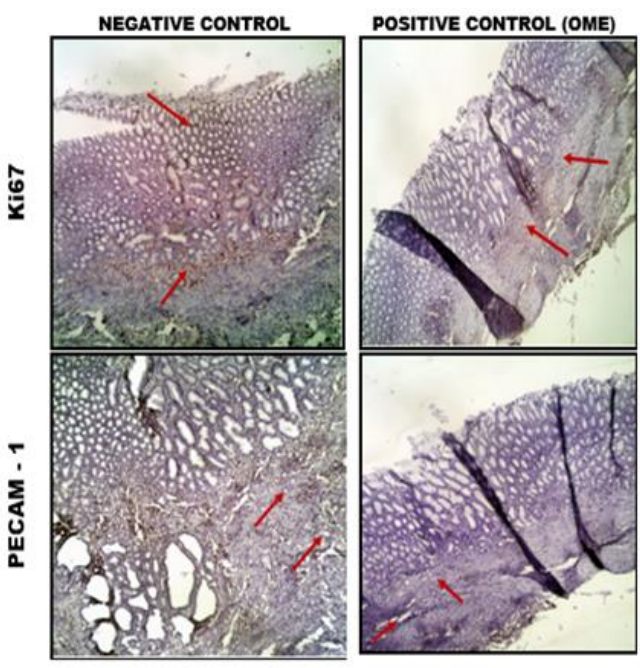
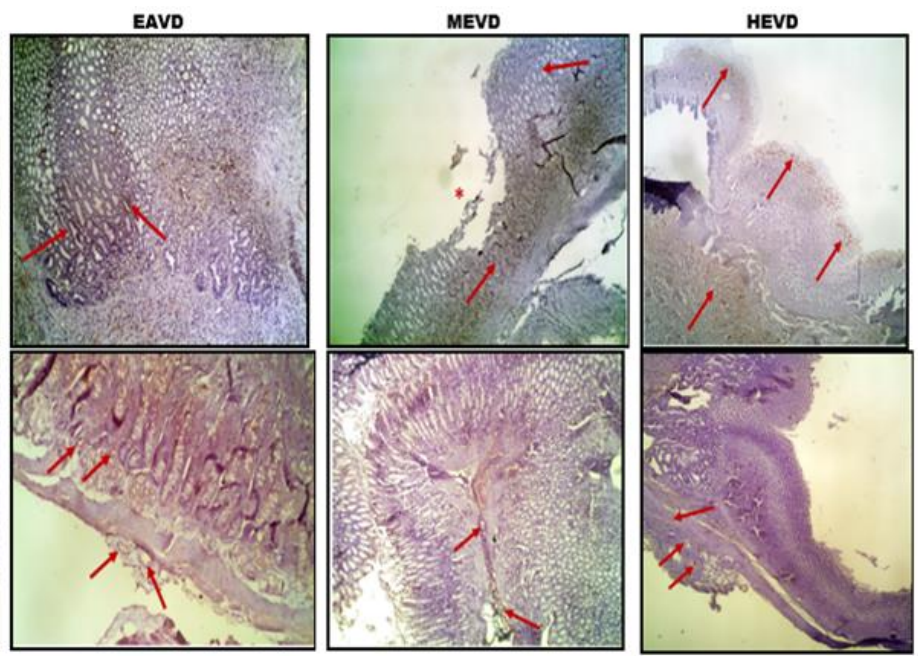

Figure 3.

Micrographs showing immunoreactivities of Ki67 and PECAM-1 (rows) of the various treatment groups (columns) The arrows point the areas of expressions of the Ki67 and PECAM-1 immunostains used

In an attempt to further purify potential biologically active compounds in the plant extract, further extractions with solvents of increasing polarity were employed in a liquid - liquid partitioning system. This method is known to be effective in separating plant phytochemicals based on solubility properties (hydrophilic or lipophilic) [23, 24]. On phytochemical analysis of the fractions, ethyl acetate and methanol fractions were found to contain mostly flavonoids, phenols and tannins while the hexane fraction contained mostly steroids and a lesser quantity of flavonoids. These findings were consistent with previous reports $[12,24,25]$ showing that phenols and tannins were extracted better in methanol than in hexane.

The antioxidant capacity of the fractions was tested by assessing their ability to scavenge DPPH radicals. The DPPH assay is a commonly used method of assessing the free radical scavenging ability of plant products because of its stable nitrogen base $[14,15]$. An estimation of the ability of potential plant based drug leads to scavenge free radicals have become necessary since free radicals (reactive oxygen and nitrogen species) have been shown to play an important role in the pathogenesis of diseases related to oxidative stress including ulcers [26].

All the fractions tested exhibited DPPH scavenging activity, but the ethyl acetate fraction had the highest scavenging capacity. This is possibly because the fraction had the highest flavonoid content and flavonoids are known to be one of the best free radical scavenging phytochemicals [11, 24]. This finding also suggests that the fractions are potentially good sources of antioxidants.

The application of acetic acid on the serosal surface of the stomach was able to produce deep ulcers in the stomach of the rats. Various necrotising agents are known to induce gastric ulcerations via several mechanisms including alteration of blood flow, ion balance and increased secretion of pepsin. The use of acetic acid is however favoured because of its ability to produce ulcers closely resembling human ulcers in rats [27-29]. These ulcers have also been known to be chronic and prone to relapsing making it an ideal model for studying potential ulcer healing drugs [30]. On exposure to acetic acid, a sequence of events occurs eventually culminating in ulcerations. First, there is dilation of the large blood vessels in the submucosa. This is followed by development of thrombi in the submucosa veins, microvascular stasis and mucosal necrosis [31, 32].

Following ulcer induction and a 14 day treatment with the plant fractions, the excised stomach mucosae of the treated animals were assessed to determine the extent of ulcer healing. It was observed that the treatment with the fractions or standard drug (omeprazole) improved healing of the ulcers compared to the negative (untreated) control. Both methanol and hexane fraction however significantly improved the healing of the ulcers performing better effects than omeprazole (the standard drug) in this study.

Omeprazole is a class of benzimidazoles which are able to inhibit the proton pumps in gastric parietal cells ultimately supressing gastric acid secretion and is able to exert its action for up to four days after cessation of administration [33, 34]. Omeprazole has also been shown to possess vasodilation properties via the selective inhibition of gastric carbonic anhydrase IV making it an effective therapy for gastric ulcers as it improves gastric mucosal perfusion while decreasing gastric acid secretion concomitantly [35].

From the phytochemical analysis of the fractions, the methanol fraction was seen to have a high concentration of tannins. Other phytochemicals moderately present were flavonoids, terpenoids and alkaloids. The hexane 
FARMACIA, 2021, Vol. 69, 6

fraction does not contain tannins but had flavonoids and steroids. All these secondary metabolites are known to possess desirable pharmacological activities [2, 36]. Tannins, for instance, are polyphenols which have been shown to possess antiulcer activity, owing it to its astringent and styptic properties. It has been suggested that these metabolites are capable of interacting with proteins to form tannin-protein complexes which essentially forms a protective layer allowing epithelia tissue injury sites to heal naturally with minimal interference. It has also been suggested that tannins possess antiseptic properties as well as being potent antioxidants [2, 37].

Alkaloids are high molecular weight nitrogen containing phytochemicals derived from amino acids and found as secondary metabolites in some plants. Many of them have been shown to possess antiulcer mechanisms by inhibiting gastric acids and stimulating mucus production and in other cases improving blood flow [38, 39].

Flavonoids are one of the most studied secondary metabolites. They are low molecular weight phenolic compounds having the benzo-y-pyrone ring. They have been shown to have several pharmacological activities including anti-inflammatory, antioxidant and antimicrobial [40, 41]. Other studies have shown that flavonoids have membrane stabilising properties and the ability to increase gastric prostaglandins [42 - 44]. Steroids are also biologically active phytochemicals known to lower cholesterol levels. Other biological activities reported are mostly speculative, even though some have reported that it possesses membrane altering effects [45].

The gastric mucus layer is considered as the first line of defence of the integrity of the gastric mucosa. The gastric mucus layer contains mucin, buffers and phospholipids providing a continuous protective covering tightly adhering to the epithelial surface [46]. In this study the expression of mucins in the gastric mucosa was assessed using the periodic acid Schiff (PAS) technique. It was observed that positive control, methanol fraction and hexane fraction groups all had moderate expressions of mucins in both surface and deep mucosal areas while the negative control group and ethyl acetate group had only mild expressions. This suggests that the plant phytochemicals may have influenced the biosynthesis of mucins which agrees with several published reports on plants with antiulcer activities in which the rats treated with the test extracts showed significantly higher expressions of mucins in the gastric mucosa [47-50].

The use of immunohistochemical methods in histopathology has become very important in determining tissue markers relevant in drug discovery [51]. In this study, two immunostains were employed to test for tissue markers relevant to gastroprotection and ulcer healing: Platelet endothelial cell adhesion molecule-1 (PECAM-1, also known as CD 31) and Ki67.
PECAM-1 is a pan-endothelial cell marker largely expressed on the surface of endothelial cells but also weakly expressed in leucocytes and lymphatic vessels to lesser extents [51]. It is primarily a cell adhesion molecule that functions to facilitate leucocyte extravasation at sites of inflammation by regulating the barrier functions of endothelial cells [52, 53]. However, it has been found that the molecule plays a key role in neovascularisation and angiogenesis making it a useful prognostic marker for this study $[54,55]$.

Angiogenesis is an important mechanism of tissue repair at sites of injury leading to the restoration of vascular networks via formation of capillaries [4, 32]. In this study, there was no expression of PECAM-1 suggestive of angiogenesis in the negative and positive control groups. However, a mild expression of the same marker was observed in all treated groups. This may be suggestive that $V$. doniana fractions may be capable of enhancing angiogenesis. As discussed earlier, alkaloids are one of the polyphenols known to alter blood flow and may have played a role in this case via a yet to be established mechanism [39].

The higher expression of PECAM-1 in this study is similar to the report by Ajayi et al. [59] in which the treatment of chronic ulcers induced by acetic acid was performed with ethanolic extract of Talinium triangulare. They reported an increase in the expression of PECAM-1 in the gastric mucosa of treated rats compared to untreated.

Ki67 antigen is a protein molecule expressed in the nucleus of proliferating cells making it a good endogenous marker for detecting epithelial proliferation [51]. Its functions in cell proliferation are not yet clearly understood but studies have shown it to be important in cell proliferation [56]. One of the most important mechanisms of gastric mucosal defence is continuous cell renewal ensuring the replenishing of epithelial cells needed to maintain the integrity of the gastric mucosa. When injury occurs to the gastric mucosa, re-epithelisation starts to occur within minutes by migration of epithelial cells which have been preserved in the neck area of the gastric glands close to the site of injury $[4,57]$.

Sections of both controls and test groups showed mild to moderate expressions of Ki67. This is expected since there is constant rapid turnover of epithelial cells in the gastric mucosa. An important observation however, is that the expression of $\mathrm{Ki} 67$ in the fractions treatment group was slightly higher than those of the controls. Moreover, the expression in the rats treated with the ethyl acetate and methanol fractions was predominantly in the deep mucosal gland regions suggesting that the fractions may have improved the proliferation of the preserved epithelial cells of the gastric neck area [4].

Several studies on ulcer healing capabilities of plant extracts have assessed epithelial cell proliferation 
using markers of cell proliferation like proliferating cell nuclear antigen (PCNA) and Ki67 with varying results. Polo et al. [3] reported that treatment of rats in which ulcers have been induced using acetic acid led to a significant decrease in the number of proliferating cells in the gastric mucosa of rats treated with essential oils from Citrus aurantium L. (Rutaceae family). Conversely, Pereira et al. [58] reported an increase in the number of proliferating cells when they assessed PCNA in rats treated with a bark extract of Tabebuia avellanedae after induction of chronic ulcers using acetic acid.

The report of the present study was however similar to that published by Ajayi et al. [59]. In their study, there was no difference in expression of Ki67 between rats treated for chronic ulcer using ethanolic extract of Talinium triangulare and the untreated ones.

Rats treated with omeprazole as a positive control had lower expression of Ki67 in their gastric mucosa. This observation was in line with the observation of Fornai et al. [60] in which the effects of esomeprazole on the healing of nonsteroidal anti-inflammatory drug (NSAID) induced gastric ulcers in rats. They reported a decrease in expression of both PCNA and Ki67 in the gastric mucosa of treated rats. These findings buttress the fact that omeprazole while being a potent drug for treatment of ulcers does not enhance cell proliferation.

\section{Conclusions}

Findings in this study suggest that Vitex doniana leaf fractions may possess ulcer healing potentials by improving some major factors of gastro-protection mucus production, epithelial cell proliferation and blood flow. These observed effects may have been as a result of the antioxidant properties of one or more of the several biologically active phytochemicals present in the plant. Other mechanisms of action may involve the plant fractions' ability to enhance angiogenesis and epithelial regeneration as well as improving mucus biosynthesis.

\section{Conflict of interest}

The authors declare no conflict of interest.

\section{References}

1. Gregory M, Divya B, Mary RA, Viji MH, Kalaichelvan VK, Palanivel V, Anti-ulcer activity of Ficus religiosa leaf ethanolic extract. Asian Pac J Trop Biomed., 2013; 3(7): 554-556.

2. de Jesus NZT, Falcão HDS, Gomes IF, Leite TJDA, Lima GRDM, Barbosa-Filho JM, Batista LM, Tannins, peptic ulcers and related mechanisms. Int J Mol Sci., 2012; 13(3): 3203-3228.

3. Polo CM, Moraes TM, Pellizzon CH, Marques MO, Rocha LRM, Hiruma-Lima CA, Gastric ulcers in middle-aged rats: The healing effect of essential oil from Citrus aurantium L.(Rutaceae). Evid Based Complement Alternat Med., 2012; 2012: 509451: 1-8.

4. Yandrapu H, Sarosiek J, Protective factors of the gastric and duodenal mucosa: an overview. Curr Gastroenterol Rep., 2015; 17(6): 24: 1-8.

5. Agbafor KN, Nwachukwu N, Phytochemical Analysis and Antioxidant Property of Leaf Extracts of Vitex doniana and Mucuna pruriens. Biochem Res Int., 2011; 2011: 459839: 1-4.

6. Dadjo C, Assogbadjo AE, Fandohan B, Kakaï1 RG, Chakeredza S, Houehanou TD, Van Damme P, Sinsin $\mathrm{B}$, Uses and management of black plum (Vitex doniana Sweet) in Southern Benin. Fruits, 2012, 67(4): 239248.

7. dos Santos MM, Olaleye MT, Ineu RP, Boligon AA, Athayde ML, Barbosa NB, Rocha JBT, Antioxidant and antiulcer potential of aqueous leaf extract of Kigelia africana against ethanol-induced ulcer in rats. EXCLI J., 2014; 13: 323-330.

8. Langmead L, Rampton DS, Review article: herbal treatment in gastrointestinal and liver disease: benefits and dangers. Aliment Pharmacol Ther., 2001; 15(9): 1239-1252.

9. Brusotti G, Cesari I, Dentamaro A, Caccialanza G, Massolini G, Isolation and characterization of bioactive compounds from plant resources: the role of analysis in the ethnopharmacological approach. J Pharm Biomed Anal., 2014; 87: 218-228.

10. Hanganu D, Benedec D, Olah NK, Ranga F, Mirel S, Tiperciuc B, Oniga I, Research on enzyme inhibition potential and phenolic compounds from Origanum vulgare ssp. vulgare. Farmacia, 2020; 68(6): 10751080.

11. Romano B, Pagano E, Montanaro V, Fortunato AL, Milic N, Borrelli F, Novel insights into the pharmacology of flavonoids. Phytother Res., 2013; 27(11): 1588-1596.

12. Azmir J, Zaidul ISM, Rahman MM, Sharif KM, Mohamed A, Sahena F, Omar AKM, Techniques for extraction of bioactive compounds from plant materials: a review. J Food Eng., 2013, 117(4): 426436.

13. Trease GE, Evans WC. Pharmacognsy. $11^{\text {th }}$ ed. Brailliar Tiridel Can. Macmillian publishers. 1989; 119.

14. Pavithra K, Vadivukkarasi S. Evaluation of free radical scavenging activity of various extracts of leaves from Kedrostis foetidissima (Jacq.) Cogn. Food Sci Human Wellness, 2015, 4(1): 42-46.

15. Sharma OP, Bhat TK, DPPH antioxidant assay revisited. Food Chem., 2009; 113(4): 1202-1205.

16. Landeira-Fernandez J, Analysis of the cold-water restraint procedure in gastric ulceration and body temperature. Physiol Behav., 2004; 82(5): 827-833.

17. Schindelin J, Arganda-Carreras I, Frise E, Kaynig V, Longair M, Pietzsch T, Preibisch S, Rueden C, Saalfeld S, Schmid B, Tinevez JY, White DJ, Hartenstein V, Eliceiri K, Tomancak P, Cardona A, Fiji: an opensource platform for biological-image analysis. Nat Methods, 2012; 9(7): 676-682.

18. Andrade SF, Antoniolli D, Comunello E, Cardoso LG, Carvalho JC, Bastos JK, Antiulcerogenic activity of crude extract, fractions and populnoic acid isolated from Austroplenckia populnea (Celastraceae). Z Naturforsch C J Biosci., 2006; 61(5-6): 329-333. 
19. Bancroft JD, Gamble M (Eds.) Theory and practice of histological techniques. Oxford: Elsevier health sciences. 2008; 113.

20. Shih SC, Robinson GS, Perruzzi CA, Calvo A, Desai K, Green JE, Ali IU, Smith LEH, Senger DR, Molecular profiling of angiogenesis markers. Am J Pathol., 2002; 161(1): 35-41.

21. Tuominen VJ, Ruotoistenmäki S, Viitanen A, Jumppanen M, Isola J, ImmunoRatio: a publicly available web application for quantitative image analysis of estrogen receptor (ER), progesterone receptor (PR), and Ki-67. Breast Cancer Res., 2010; 12(4): R56: 1-12.

22. Steven OO, Uwadiegwu AP, Chinonyelum AN, Chukwu ND, Obianuju OA, Kingsley UI, Chekwube EB, Preliminary studies on the anti-ulcer potentials of Vitex doniana crude extracts on experimental rat model of ethanol induced gastric ulcer. Asian Pac J Trop Dis., 2016; 6(9): 736-740.

23. Cesari I, Hoerlé M, Simoes-Pires C, Grisoli P, Queiroz EF, Dacarro C, Marcourt L, Moundipa PF, Carrupt PA, Cuendet M, Caccialanza G, Anti-inflammatory, antimicrobial and antioxidant activities of Diospyros bipindensis (Gürke) extracts and its main constituents. J Ethnopharmacol., 2013; 146(1): 264-270.

24. Yakubu OE, Nwodo OFC, Joshua PE, Ugwu MN, Odu AD, Okwo F, Fractionation and determination of total antioxidant capacity, total phenolic and total flavonoids contents of aqueous, ethanol and n-hexane extracts of Vitex doniana leaves. Afr J Biotechnol., 2014; 13(5): 1-11.

25. Ali M, Aminu F, Ibrahim IS, In-Vitro Assessment of Antibacterial Activity and Phytochemical Screening of Vitex Doniana on Clinical Isolate of Salmonella Typhi. Int J Advanced Acad Res., 2017; 3(1): 1-8.

26. Halliwell B, Gutteridge JM, Role of free radicals and catalytic metal ions in human disease: an overview. Methods Enzymol., 1990; 186: 1-85.

27. Takagi K, Okabe S, Saziki R, A new method for the production of chronic gastric ulcer in rats and the effect of several drugs on its healing. Jpn J Pharmacol., 1969; 19(3): 418-426.

28. Okabe S, Amagase K, Takeuchi K, Acetic Acid Ulcer Model-State of the Art in 2012. In: Cell/Tissue Injury and Cytoprotection/Organoprotection in the Gastrointestinal Tract, Filaretova LP, Takeuchi K, (Eds.). Vol. 30, Karger Publishers Co., France, 2012; 239-245.

29. Sarkar S, Sengupta A, Mukhrjee A, Guru A, Patil A, Kandhare AD, Bodhankar SL, Antiulcer potential of morin in acetic acid-induced gastric ulcer via modulation of endogenous biomarkers in laboratory animals. Pharmacologia, 2015; 6(7): 273-281.

30. Adinortey MB, Ansah C, Galyuon I, Nyarko A, In vivo models used for evaluation of potential antigastroduodenal ulcer agents. Ulcers, 2013; 2013: 796405: 1-7.

31. Ahluwalia A, Tarnawski AS, Critical role of hypoxia sensor- -HIF- $1 \alpha$ in VEGF gene activation. Implications for angiogenesis and tissue injury healing. Curr Med Chem., 2012; 19(1): 90-97.

32. Syam AF, Sadikin M, Wanandi SI, Rani AA, Molecular mechanism on healing process of peptic ulcer. Acta Med Indones, 2009; 41(2): 95-98.
33. Ahmad L, Iqbal Z, Shah Y, Nazir S, Khan A, Khan MI, Khan A, Khuda F, Khan I, Comparative pharmacokinetics of Omeprazole and its metabolites in poor and extensive metabolizer Pakistani healthy volunteers and a review of different studies. Pak J Pharm Sci., 2018; 31(4): 1363-1374.

34. Zimmermann AE, Walters JK, Katona BG, Souney $\mathrm{PF}$, Levine D, A review of omeprazole use in the treatment of acid-related disorders in children. Clin Ther, 2001; 23(5): 660-679.

35. Mullin JM, Gabello M, Murray LJ, Farrell CP, Bellows J, Wolov KR, Kearney KR, Rudolph D, Thornton JJ, Proton pump inhibitors: actions and reactions. Drug Discov Today, 2009; 14(13-14): 647-660.

36. Farzaei MH, Abdollahi M, Rahimi R, Role of dietary polyphenols in the management of peptic ulcer. World J Gastroenterol., 2015; 21(21): 6499-6517.

37. Souza SMC, Aquino LCM, Milach AC Jr, Bandeira MAM, Nobre MEP, Viana GSB, Antiinflammatory and antiulcer properties of tannins from Myracrodruon urundeuva Allemão (Anacardiaceae) in rodents. Phytother Res., 2007; 21(3): 220-225.

38. de Sousa Falcão H, Leite JA, Barbosa-Filho JM, de Athayde-Filho PF, de Oliveira Chaves MC, Moura MD, Ferreira AL, Albino de Almeida AB, SouzaBrito ARM, de Fátima Formiga Melo Diniz M, Gastric and duodenal antiulcer activity of alkaloids: a review. Molecules, 2008; 13(12): 3198-3223.

39. Souto AL, Tavares JF, Sobral da Silva M, de Fátima Formiga Melo Diniz M, de Athayde-Filho PF, Barbosa Filho JM, Anti-inflammatory activity of alkaloids: an update from 2000 to 2010. Molecules, 2011; 16(10): 8515-8534.

40. Bulgari M, Sangiovanni E, Colombo E, Maschi O, Caruso D, Bosisio E, Dell'Agli M, Inhibition of neutrophil elastase and metalloprotease- 9 of human adenocarcinoma gastric cells by chamomile (Matricaria recutita L.) infusion Phytother Res., 2012; 26(12): 1817-1822.

41. Awaad AS, Al-Jaber NA, Moses JE, El-Meligy RM, Zain ME, Antiulcerogenic activities of the extracts and isolated flavonoids of Euphorbia cuneata Vahl. Phytother Res., 2013; 27(1): 126-130.

42. Nartey ET, Ofosuhene M, Kudzi W, Agbale CM, Antioxidant and gastric cytoprotective prostaglandins properties of Cassia sieberiana roots bark extract as an anti-ulcerogenic agent. BMC Complement Med Ther., 2012; 12: 65: 1-10.

43. Im WJ, Nam Y, Park SY, Sohn UD, Gastroprotective effect of the three glucuronopyranoside flavonoids in rats. Korean J Physiol Pharmacol., 2013; 17(5): 411-415.

44. Ahmed F, Rahman MS, Preliminary assessment of free radical scavenging, thrombolytic and membrane stabilizing capabilities of organic fractions of Callistemon citrinus (Curtis.) skeels leaves. BMC Complement Med., 2016; 16: 247: 1-8.

45. de Jong A, Plat J, Mensink RP, Metabolic effects of plant sterols and stanols (Review). J Nutr Biochem., 2003; 14(7): 362-369.

46. Sarosiek J, Jensen RT, Maton PN, Peura DA, Harlow D, Feng T, McCallum RW, Pisegna JR, Salivary and gastric epidermal growth factor in patients with 
Zollinger-Ellison syndrome: its protective potential. Am J Gastroenterol., 2000; 95(5): 1158-1165.

47. Pereira IT, Burci LM, da Silva LM, Baggio CH, Heller M, Micke GA, Pizzolatti MG, Marques MC, de Paula Werner MF, Antiulcer effect of bark extract of Tabebuia avellanedae: activation of cell proliferation in gastric mucosa during the healing process. Phytother Res., 2013; 27(7): 1067-1073.

48. AL-Yahya AA, Asad M, Antiulcer activity of gum arabic and its interaction with antiulcer effect of ranitidine in rats. Biomed Res., 2016; 27(4): 1102-1106.

49. Adhikary B, Yadav SK, Roy K, Bandyopadhyay SK, Chattopadhyay S, Black tea and theaflavins assist healing of indomethacin-induced gastric ulceration in mice by antioxidative action. Evid Based Complementary Altern Med., 2011; 2011: 546560: 1-11.

50. Groșan A, Ștefănescu R, Gurzu S, Muntean DL, Vlase L, Vari CE, Study of the potential antiulcerous action of hydroalcoholic extracts from Prunella vulgaris 1 . of Romanian origin. Farmacia, 2020; 68(5): 870-881.

51. Potts SJ, Eberhard DA, Wharton KA (Eds.). Molecular Histopathology and Tissue Biomarkers in Drug and Diagnostic Development. Humana Press. 2015; 11-21.

52. Bixel MG, Li H, Petri B, Khandoga AG, Khandoga A, Zarbock A, Wolburg-Buchholz K, Wolburg H, Sorokin L, Zeuschner D, Maerz S, Butz S, Krombach F, Vestweber D, CD99 and CD99L2 act at the same site as, but independently of, PECAM-1 during leukocyte diapedesis. Blood, 2010; 116(7): 1172-1184.

53. Chistiakov DA, Orekhov AN, Bobryshev YV, Endothelial PECAM-1 and its function in vascular physiology and atherogenic pathology. Exp Mol Pathol., 2016; 100(3): 409-415.
54. Park S, Sorenson CM, Sheibani N, PECAM-1 isoforms, eNOS and endoglin axis in regulation of angiogenesis. Clin Sci., 2015; 129(3): 217-234.

55. Cao G, O'Brien CD, Zhou Z, Sanders SM, Greenbaum JN, Makrigiannakis A, DeLisser HM, Involvement of human PECAM-1 in angiogenesis and in vitro endothelial cell migration. Am J Physiol Cell Physiol., 2002; 282(5): C1181-C1190.

56. Brown DC, Gatter KC, Ki67 protein: the immaculate deception?. Histopathology, 2002; 40(1): 2-11.

57. Fornai M, Antonioli L, Colucci R, Tuccori M, Blandizzi C, Pathophysiology of gastric ulcer development and healing: molecular mechanisms and novel therapeutic options, in Peptic Ulcer Disease, Edited by Dr. Jianyuan Chai, Publisher InTech, 2011; 113-142.

58. Pereira IT, Burci LM, da Silva LM, Baggio CH, Heller M, Micke GA, Pizzolatti MG, Marques MCA, de Paula Werner MF, Antiulcer effect of bark extract of Tabebuia avellanedae: activation of cell proliferation in gastric mucosa during the healing process. Phytother Res., 2013; 27(7): 1067-1073.

59. Ajayi AF, Folawiyo AB, Salami TA, Ulcer Healing Mechanism of Ethanolic Extract of Talinium triangulare in Male Wistar Rats. UK J Pharm Biosci., 2016, 4(4), 41-50.

60. Fornai M, Rocchina C, Luca A, Oriana A, Clara U, Marco T, Federica F, Gianfranco N, Fulvio B, Corrado $\mathrm{B}$, Effects of esomeprazole on healing of nonsteroidal anti-inflammatory drug (NSAID)-induced gastric ulcers in the presence of a continued NSAID treatment: Characterization of molecular mechanisms. Pharmacol Res., 2011; 63(1): 59-67. 